\title{
International Students' Experiences Developing Leadership Capacity on Host Campuses
}

\author{
David H. K. Nguyen
}

\section{Introduction}

Research on international students is new and expanding, but few empirical studies have examined how student leadership theory impacts the educational success of international students. Student involvement (Kuh, 2001) and student leadership (Astin \& Astin, 2000; Roberts, 2003) can have a positive effect on students' academic and social outcomes on campus. Leadership capacity and efficacy are linked to important academic, career, and life benefits, such as career and leadership aspirations, work performance, the ability to cope and overcome stereotypes, and the adaptation to and persistence in the face of challenging situations (Day, Harrison, \& Halpin, 2009; Machida \& Schaubroeck, 2011). As a result, increasing student involvement opportunities for international students and engaging them in leadership opportunities on campus may not only increase their educational success and career aspirations, but it will also be critical to integrating them on campus and developing their own diverse perspectives. Adding the international student voice to the literature will help institutions understand their experiences and how administrators and professionals can further improve their collegiate experience.

International students have "remained one of the most quiet, invisible, underserved groups on the American campus" (Mori, 2000, p. 143). While research has found that student involvement and leadership opportunities have an impact on student success and retention (Astin, 1993; Seidman, 2005), the research has concentrated on domestic students. Research on the development of leadership 
capacity in international students is absent from the national discourse in higher education. As a result, the purpose of this study was to examine leadership capacity and self-efficacy among international students and learn about those campus activities that promote positive leadership self-efficacy. In this study, I asked the primary research question: How do campus environments influence the leadership self-efficacy of international student populations?

\section{Student Leadership Development}

The college environment is an optimal space to develop leaders through organizational involvement and positional opportunities on campus. Given that leadership is an integral purpose of higher education (Dugan \& Komives, 2007), it is important to understand how students fit into this complex concept. Student leadership has been an area that has been reexamined and reassessed over the past decades due to the diverse needs of students (Kezar, Carducci, \& Contraras-McGavin, 2006). Komives, Owen, Longerbeam, Mainella, and Osteen (2005) found that as students entered college, their approach to leadership appeared to be consistent to the industrial forms of the leader-centric and personal abilities models. As students developed throughout their years in higher education, their understanding of leadership shifted to become more relational, similar to the post-industrial leadership model (Komives, Longerbeam, Owen, Mainella, \& Osteen, 2006). Students' college experiences can change the way they think about leadership, which can also shift their perceptions of leadership efficacy.

Astin (1997) called for different kinds of campus student leaders "who are actively engaged in making a positive difference in society ... as an effective social change agent" (p. 9). Instead of the traditional view that leaders have innate traits or abilities, this view sees every student as a potential leader (Astin, 1997). Astin, Astin, \& Associates's (1996) Social Change Model is the most widely used of the student leadership models (Kezar et al., 2006; Moriarty \& Kezar, 2000), was specifically designed for college students, and states that leadership is tied to social responsibility to create change for the 
9 International Students' Experiences Developing Leadership Capacity on Host Campuses

common good and that its purpose is to increase individuals' levels of self-knowledge and capacity to work collaboratively with others (HERI, 1996). This is achieved by growth in the critical areas of consciousness of self, congruence, commitment, collaboration, common purpose, controversy with civility, and citizenship. These factors contribute to the common good (HERI).

\section{Leadership Self-Efficacy}

Leadership self-efficacy is derived from the concept of self-efficacy, which is the belief that one has the capabilities and resources to perform a specific task and is grounded in social cognitive theory (Bandura, 1997), but it is better to understand self-efficacy through a field such as leadership. Among the theories that inform leadership research, self-efficacy was one of the top five credible theories as reported by scholars (Lee \& Early, 1992). This personal belief can change based on different factors of function, such as self-esteem, competency, and environment (McCormick, Tanguma, \& Lopez-Forment, 2002). It can also be affected by how a person learns behaviors throughout his or her development, which influences his or her judgment and decision-making (Bandura, 1997).

Literature defines self-efficacy of leadership as the belief in one's ability to engage in leadership practice by organizing and executing necessary courses of action (Denzine, 1999). Chemers (2000) describes leadership self-efficacy as a basis from which to understand one's leadership performance and asserts that one's confidence can help develop mastery to become a better leader. In other words, selfefficacy in leadership refers to one's confidence in his or her ability to lead, and this frequently impacts whether or not one decides to lead (Komives \& Dugan, 2010; Murphy, 2002; Paglis, 2010). Self-efficacy is a critical factor to the leadership development process (Komives et al., 2006). It has been found that self-efficacy is highly related to the frequency with which a person reports an attempt to lead (McCormick et al., 2002).

Leadership self-efficacy can be a predictor of leadership performance. Personal and situational factors can impact leadership self-efficacy, which in turn influence students' behavior and performance. In Chemers, Watson, and May (2000), self-rated leadership efficacy was connected to evaluations of 
9 International Students' Experiences Developing Leadership Capacity on Host Campuses

leadership by peers, instructors, and third-party observers, and efficacy contributes to actual performance and not just the perception of competency. However, efficacy is fluid and is influenced by environmental factors that may either leverage or constrain an individual's perceptions of his or her capacity for leadership (Bandura, 1997). International students may have different leadership efficacies than their domestic student peers depending on their learning environments and the culture of their home countries and communities. Enhancing international students' efficacy for leadership may create positive environments for positive academic success and career outcomes.

\section{Collegiate Environments and Leadership Self-Efficacy}

There is a positive relationship between participation in college leadership opportunities and leadership skills and abilities. A multitude of co-curricular experiences can contribute to the development of these skills and abilities. Co-curricular experiences are defined as membership and participation in student clubs and organizations, such as student government, debate teams, campus newspapers, and social fraternal organizations, or academic programs, such as living-learning programs (Newcomb, 1962; Weidman, 1989), and many scholars have examined how these activities and experiences influence leadership (Antonio, 2001; Dugan, 2006; Thompson, 2006).

Students that participate in leadership programs have also showed larger gains in leadership knowledge, skills, and abilities than those who did not participate in these kinds of activities (Dugan \& Haber, 2007; Zimmerman-Oster \& Burkhardt, 1999). Student involvement outside of the classroom both on and off campus, including community service and employment, has a positive relationship with leadership development through skill building (Astin, 1993; Lambert, Terenzini, \& Luttuca, 2006). Student involvement is particularly helpful to facilitate learning in ethnic students (Kezar \& Moriarty, 2000). The development of these skills contributes to an individual's mastery experiences and builds upon their confidence for leadership, and consequently, their leadership self-efficacy.

\section{Cultural Differences}


Culture can influence leadership concepts (House et al., 2004). Differences arise in how leadership is rooted within different systems of cultural practices and values (Chhokar, Brodbeck, \& House, 2013), and even within a common continent, Ronen and Shenkar (1985) found that clusters of European countries that share similar cultural values also share similar leadership concepts. Countries that cluster together are based on geographical proximity, common language or language groups, religion, and economic, political, educational, and social development (Hofstede, 1980; Ronon \& Shenkar, 1985). Some of these determine cultural values, such as individualism, impacting the dimensions of leadership. These cultural dimensions are highly correlated with leadership dimensions (Smith, Dugan, \& Trompenaars, 1996). Although this study does not examine the differences of leadership self-efficacy based on these cultural clusters because of the limitations of the survey, it is important to note the impact of culture on these differences in leadership capacity and self-efficacy.

\section{Conceptual Framework}

Astin's (1993) Inputs-Environment-Outcome (IEO) college impact model, which allows the researcher to "assess the impact of various environmental experiences by determining whether students grow or change differently under varying environmental conditions" (p. 7), is the conceptual framework that influenced the Multi-Institutional Study of Leadership (MSL) instrument used in this study. While Astin's (1991) traditional IEO model assumes that data collection happens at a minimum of two different points to capture change, the model was adapted for the MSL from the pre-/postassessment to a design that collected retrospective data at a single point. As a result, the MSL instrument asks students to retroactively reflect upon their prior knowledge and experiences. This then/now approach provides a more accurate measure of self-reported leadership development by reducing the amount of response shift bias (Howard, 1980; Howard \& Dailey, 1979; Rohs, 1999, 2002; Rohs \& Langone, 1997). Therefore, while the participants were in college, they answered questions that asked about their pre-collegiate activities and characteristics while also capturing environmental data, such as their current college leadership, institutional type, student status, racial group, perceptions of 
campus climate, and class standing (Astin, 1993; Dugan \& Komives, 2011; Pascarella \& Terenzini, 2005). The purpose of this model is to allow researchers to modify the inputs or students' background characteristics to provide a more representative estimate of the influences of different college environments on student outcomes (Astin, 1991). The independent variables in this study are the inputs and environments, while the outcomes are the dependent variables.

[Insert 15032-2112-PII-009-Figure-001 Here]

Figure 9.1 Multi-Institutional Study of Leadership Conceptual Model (2012)

Source: Multi-Institutional Study of Leadership, 2012

For example, as seen in Figure 9.1 inputs refer to student background characteristics prior to enrolling in their current higher education institution. These variables can be either fixed characteristics (i.e., student demographics) or variable characteristics that can change over time, such as aptitude or values (Astin, 1991). In this study, these may include immigration status, class level, family income, gender, etc. The pre-tests (i.e., leadership self-efficacy pre-test) in this study can also serve as inputs for the outcome measures. Environments, on the other hand, are the experiences gained during college. The college environment includes everything that a student encounters during the course of their studies that may influence their education outcome (Astin, 1991), such as programming, residential life, positional leadership, mentoring, etc. Lastly, outcomes are the development in students that institutions aim to influence through the college environment. Outcomes can be categorized as cognitive (knowledge and reasoning) or affective (attitudes, values, beliefs, etc.). In this study, one of the outcomes is leadership self-efficacy. This framework is appropriate for this study since it is the basis of the survey instrument used to collect the data. In addition, to date, there are no theories or frameworks that examine student leadership with a particular lens on international students. 


\section{Research Method}

This quantitative study was a secondary analysis of data collected by the Multi-Institutional Study of Leadership (MSL). This dataset provided a national sample of self-reported data from students at a variety of institutions. The study used a comparative design to answer the research question. In order to accurately assess the role of the college environment on educational outcomes, covariates controlled for the pre-college characteristics and other confounding factors. For this study, data from students who indicated their international student status were analyzed.

\section{Multi-Institutional Study of Leadership (MSL)}

The MSL was designed to examine and understand college student leadership development and the impact of college environments on leadership outcomes (Dugan \& Komives, 2007). The conceptual model is based on Astin's (1991) college impact model that controlled for pre-collegiate characteristics, inputs (I), while assessing the impact of college environments (E) on student outcomes (O). The IEO model uses a longitudinal design with pre- and post-tests. The MSL, however, used an adapted version of the IEO model and applied a one-time post-test design that incorporated a quasi-pre-test in the instrument.

\section{Study Participants}

The 2012 MSL sample consisted of 91,178 study participants from eighty-two enrolled institutions. There was a 33\% response rate from a total of 276,297 students who were sent surveys, which falls in the acceptable rate of response for Internet surveys (Crawford, Couper, \& Lamia, 2001). From the total 91,178 students who responded to the survey, only 78,146 students responded to the question pertaining to their citizenship and generational status, of which 3,430 students answered positive as international students. 


\section{Data Analysis}

Given the dependent and independent variables, I elected to conduct multiple regression analyses to answer the research question in this study and examine how student demographics, their pre-collegiate self-efficacy of leadership, pre-collegiate student engagement experiences, and collegiate student engagement experiences impact their leadership self-efficacy.

The regression equation used for this analysis was:

$$
\mathrm{LSE}_{\mathrm{POST}}=\beta_{0}+\beta_{1}[\mathrm{DEMO}]+\beta_{2}[\mathrm{PRE}-\mathrm{COLL}]+\beta_{3} \mathrm{LSE}_{\mathrm{PRE}}+\beta_{4}\left[\mathrm{COLL} \_\mathrm{EXP}\right]+\varepsilon,
$$

where $L S E_{\text {Post }}$ is the leadership self-efficacy post-test rating; DEMO is a vector comprising student demographics; PRE-COLL is a vector comprising student pre-collegiate engagement experiences; $L_{S E} E_{P R E}$ is the leadership self-efficacy pre-test; COLL_EXP is a vector of collegiate student engagement; and $\varepsilon$ is the error term. The predicted outcome of leadership self-efficacy from the post-test equals the sum of the intercept, the coefficient of the vector comprising student demographics, the coefficient of the vector comprising student pre-collegiate engagement experiences, the students' leadership self-efficacy pretest dummy variable, and the coefficient of the vector of student collegiate experiences.

\section{Results}

The first set of environmental variables examined the international students' experience with a wide variety of campus activities. For example, results in Table 9.1 are expected and consistent with current research; students who studied abroad and participated in a first year or freshman seminar course had positive gains in leadership self-efficacies. However, those who worked off campus, engaged in community service, and had practical experience reported negative gains in leadership self-efficacy; those international students who worked off campus reported much less gain in leadership self-efficacy than their peers. 
9 International Students' Experiences Developing Leadership Capacity on Host Campuses

Table 9.1 Impact of Various Campus-Wide Activities on International Students' LSEPOST 
9 International Students' Experiences Developing Leadership Capacity on Host Campuses

\begin{tabular}{|c|c|c|c|c|}
\hline \multirow{2}{*}{ Environmental Variables } & \multicolumn{2}{|c|}{ Unstandardized Coefficients } & \multicolumn{2}{|c|}{ Unstandardized Coefficients } \\
\hline & B & Std. Error & B & Std. Error \\
\hline Collegiate environments & & & & \\
\hline ENV1: Are you currently working off & & & & \\
\hline $\begin{array}{l}\text { campus in a position unaffiliated } \\
\text { with your school? }\end{array}$ & -0.128 & 0.005 & -0.064 & 0.004 \\
\hline $\begin{array}{l}\text { ENV3: In an average month, do you } \\
\text { engage in any community service? }\end{array}$ & $-0.051 L^{*}$ & 0.005 & -0.034 & 0.004 \\
\hline ENV4A: Study abroad & $0.021 \stackrel{* * *}{\leftarrow}$ & 0.006 & $0.0277^{* * *}$ & 0.005 \\
\hline ENV4B: Practicum, internship, field & & & & \\
\hline $\begin{array}{l}\text { experience, co-op experience, or } \\
\text { clinical experience }\end{array}$ & $-0.0644^{* * * *}$ & 0.005 & $-0.018 \stackrel{\text { **** }}{\square}$ & 0.004 \\
\hline $\begin{array}{l}\text { ENV4F: First year or freshman } \\
\text { seminar course }\end{array}$ & $0.0411^{* * *}$ & 0.004 & $0.026^{* * *}$ & 0.004 \\
\hline Student demographics & & & $x$ & $\mathrm{x}$ \\
\hline
\end{tabular}


9 International Students' Experiences Developing Leadership Capacity on Host Campuses

\begin{tabular}{|c|c|c|c|c|}
\hline Pre-collegiate environments & & & $x$ & $x$ \\
\hline Leadership self-efficacy pre-test & & & $\mathrm{X}$ & $\mathrm{X}$ \\
\hline (Constant) & $2.780^{* * * *}$ & 0.049 & $1.306{ }^{* * * *}$ & 0.046 \\
\hline Adj. R-squared & 0.201 & & 0.402 & \\
\hline
\end{tabular}

NOTES:

*** $p<0.01$

(1) Student demographics included international student status, gender, race, academic major, class standing, class GPA, interactions: gender * major, gender * race

(2) Pre-collegiate environments included variables PRE3A, PRE3B, PRE3C, PRE4A, PRE4C, PRE4D, PRE4F, PRE4G

Results in Table 9.2 illustrate that students who had experiences in organizational leadership reported positive gains in their leadership self-efficacy. Students who had been involved in an organization and had held a leadership position reported larger gains in their leadership self-efficacy than those who were involved only as a member and having a leadership position on campus has a larger effect than a leadership position in an off campus community organization.

Table 9.2 Impact of Organizational Leadership on International Students' LSE 
9 International Students' Experiences Developing Leadership Capacity on Host Campuses

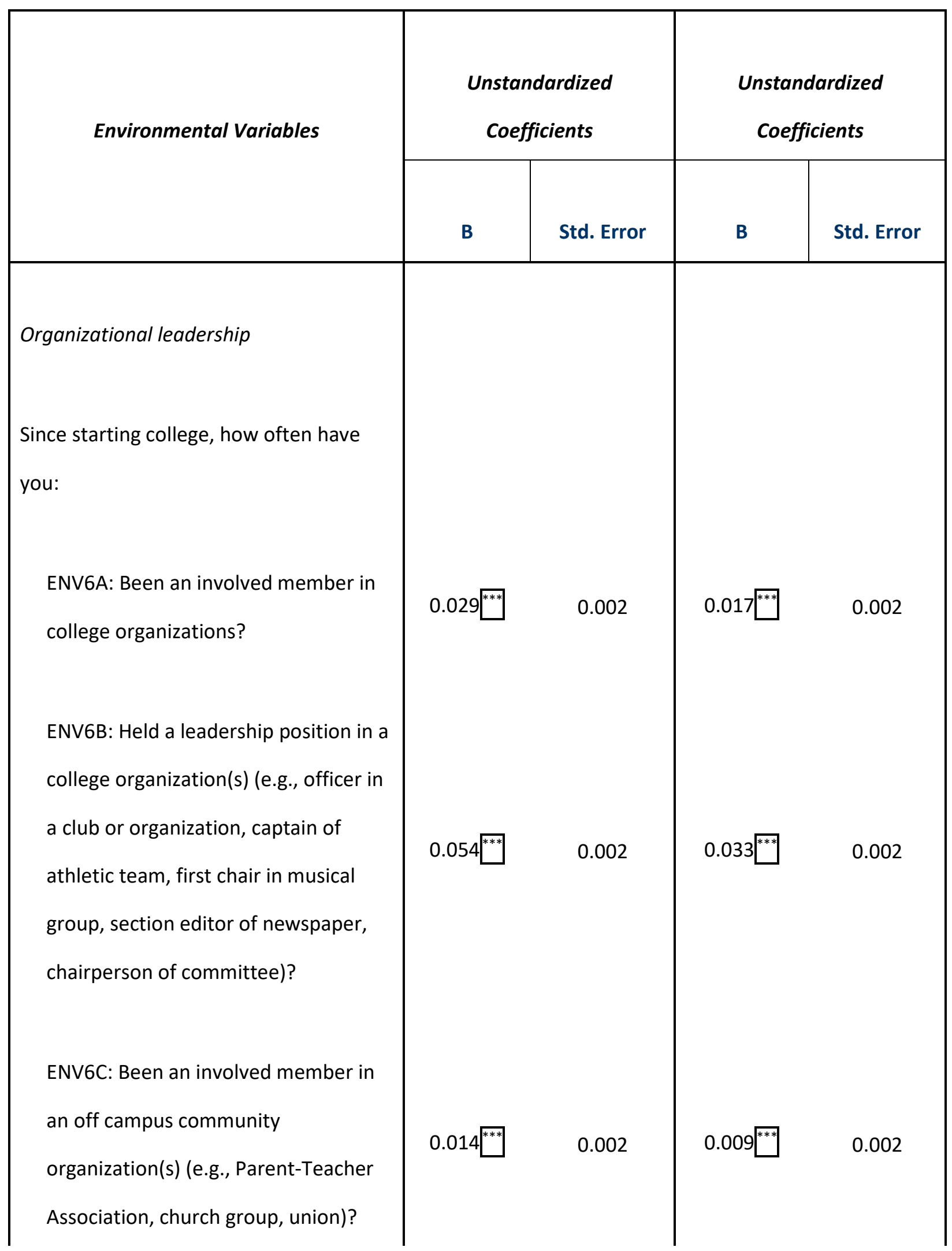


9 International Students' Experiences Developing Leadership Capacity on Host Campuses

\begin{tabular}{|c|c|c|c|c|}
\hline $\begin{array}{l}\text { ENV6D: Held a leadership position in } \\
\text { an off campus community }\end{array}$ & & & & \\
\hline $\begin{array}{l}\text { organization(s) (e.g., officer in a club } \\
\text { or organization, officer in a } \\
\text { professional association, chairperson } \\
\text { of a committee)? }\end{array}$ & $0.048^{* * * *}$ & 0.003 & $0.017 \stackrel{* * *}{\leftarrow}$ & 0.002 \\
\hline Student demographics & & & $\mathrm{X}$ & $\mathrm{X}$ \\
\hline Pre-collegiate environments & & & $X$ & $X$ \\
\hline Leadership self-efficacy pre-test (LSE $\left.E_{P R E}\right)$ & & & $\mathrm{X}$ & $X$ \\
\hline (Constant) & $2.780 \stackrel{* * * 7}{\circ}$ & 0.049 & $1.306^{* * *}$ & 0.046 \\
\hline Adj. R-squared & 0.201 & & 0.402 & \\
\hline
\end{tabular}

NOTES:

$\stackrel{* * *}{*} p<0.01$

(1) Student demographics included international student status, gender, race, academic major, class standing, class GPA, interactions: gender * major, gender * race 
9 International Students' Experiences Developing Leadership Capacity on Host Campuses

(2) Pre-collegiate environments included variables PRE3A, PRE3B, PRE3C, PRE4A, PRE4C, PRE4D, PRE4F, PRE4G

Student involvement is a critical aspect of the college experience. While many student involvement activities have positive influences on leadership self-efficacy, others show negative gains. For example in Table 9.3, for international students, the activities that show the largest positive effects are art/theater/music, religious, intercollegiate athletics, and multi-cultural fraternities and sororities. Activities that do not increase leadership self-efficacy are academic/departmental/professional, campuswide programming, peer-helper, political, student government, and military groups. The contrasting results may be a result of the kind of environment that is created in each of these types of activities. Table 9.3 Impact of Student Involvement Activities on International Students' LSE 
9 International Students' Experiences Developing Leadership Capacity on Host Campuses

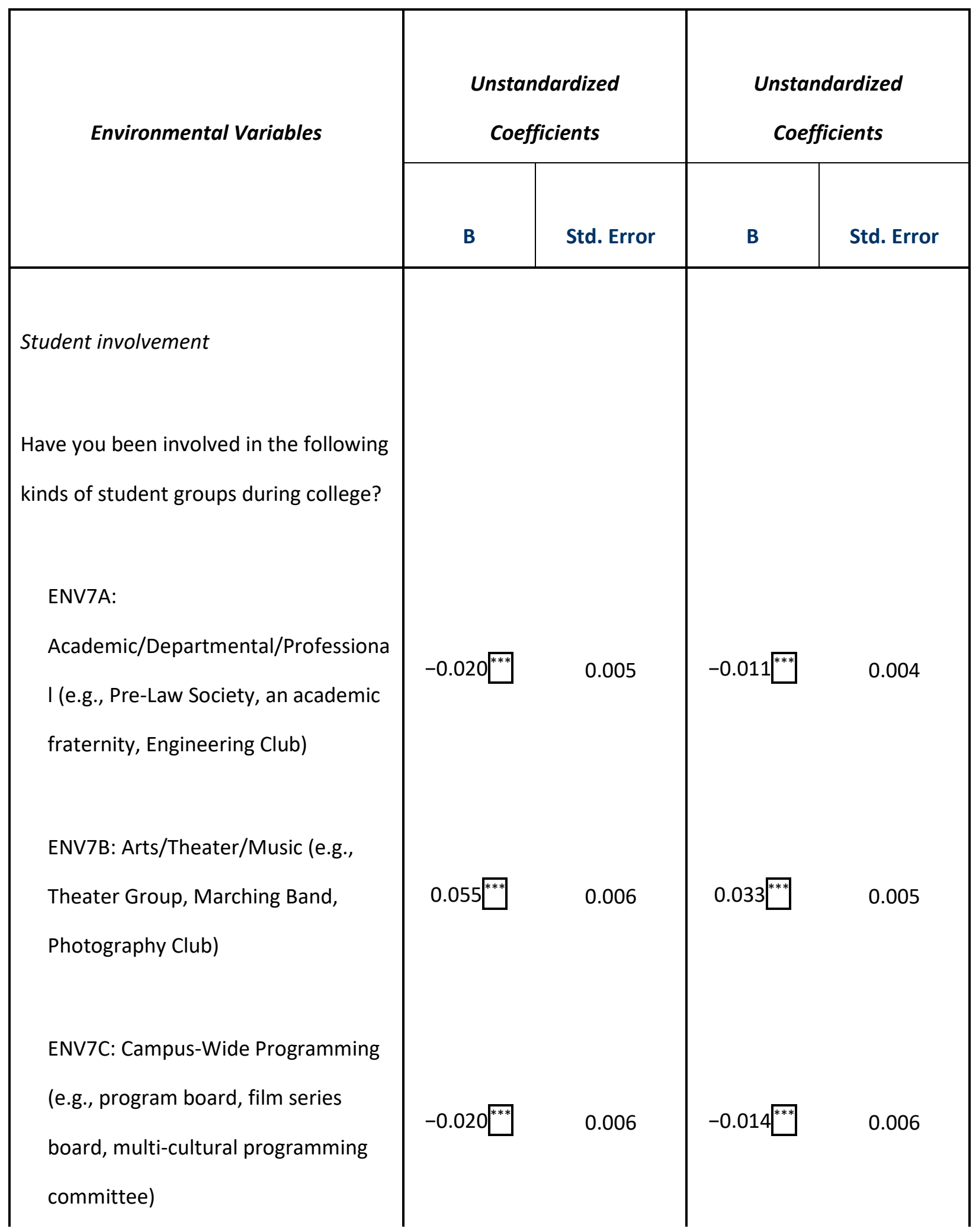


9 International Students' Experiences Developing Leadership Capacity on Host Campuses

ENV7D: Identity-Based (e.g., Black

Student Union, LGBT Allies, Korean

$0.060^{* * * *}$

0.006

0.011 ⿵

0.006

Student Association)

ENV7E: International Interest (e.g., German Club, Foreign Language

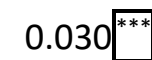

0.006

$0.013^{\text {** }}$

0.006

Club)

ENV7G: Media (e.g., Campus Radio, Student Newspaper)

0.004

0.007

$0.013^{\text {*** }}$

0.006

ENV7H: Military (e.g., ROTC, cadet corps)

$-0.138^{* * *}$

0.012

$-0.072^{* * *}$

0.011

ENV7K: Peer Helper (e.g., resident assistants, peer health educators)

$-0.018^{* *}$

0.006

$-0.018^{* * *}$

0.005

ENV7M: Political (e.g., College

Democrats, College Republicans,

$-0.054^{* * *}$

0.008

$-0.018^{\text {** }}$

0.007

Libertarians)

ENV7N: Religious (e.g., Fellowship of Christian Athletes, Hillel)

0.065 0.006

$0.037^{* * *}$ 0.005 
9 International Students' Experiences Developing Leadership Capacity on Host Campuses

ENV7O: Service (e.g., Circle K, Habitat for Humanity)

ENV7P: Multi-Cultural Fraternities and Sororities (e.g., National PanHellenic Council [NPHC] groups such as Alpha Phi Alpha Fraternity Inc., or Latino Greek Council groups such as Lambda Theta Alpha)

ENV7Q: Social Fraternities or Sororities (e.g., Panhellenic or Interfraternity Council groups such as Sigma Phi Epsilon or Kappa Kappa Gamma)

ENV7R: Sports-Intercollegiate or Varsity (e.g., NCAA Hockey, Varsity Soccer)

ENV7S: Sports-Club (e.g., Club Volleyball, Club Hockey)

ENV7T: Sports-Intramural (e.g., Intramural Flag Football)

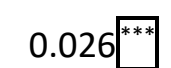

0.005

0.007

0.005

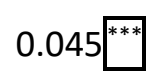

0.012

$0.029^{\text {*** }}$

0.01

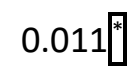

0.006

$0.015^{\text {**** }}$

0.006

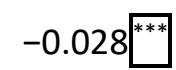

0.007

$0.038^{* * *}$

0.006

$-0.005$

0.006

$0.011^{* *}$

0.005

$-0.035^{* * *}$

0.005 $0.021^{\text {***** }}$

0.004 
9 International Students' Experiences Developing Leadership Capacity on Host Campuses

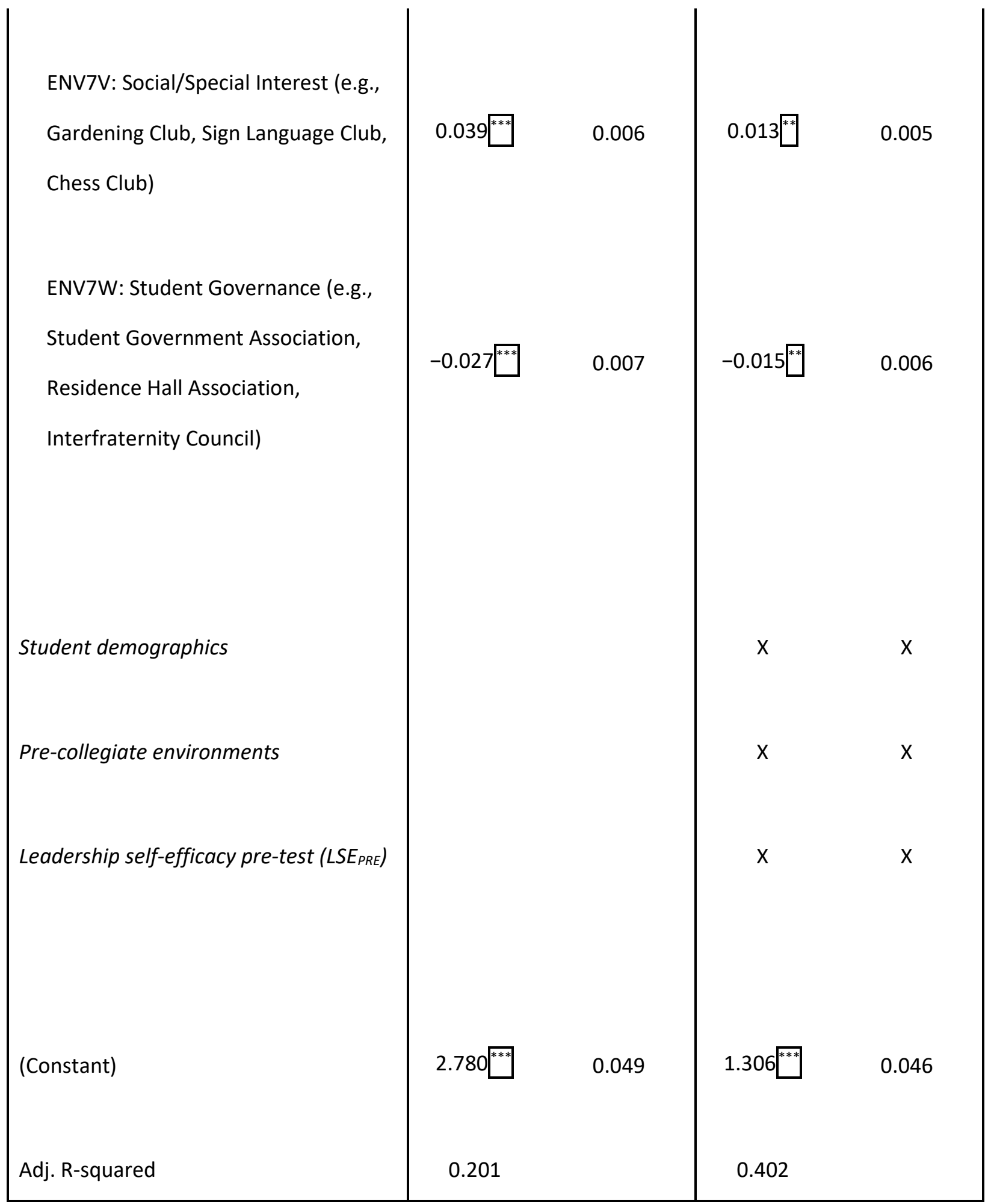

NOTES:

冈 $p<0.10$ 
9 International Students' Experiences Developing Leadership Capacity on Host Campuses

$\stackrel{\star *}{*}^{*}<0.05$

$\stackrel{* * * *}{*} p<0.01$

(1) Student demographics included international student status, gender, race, academic major, class standing, class GPA, interactions: gender * major, gender * race

(2) Pre-collegiate environments included variables PRE3A, PRE3B, PRE3C, PRE4A, PRE4C, PRE4D, PRE4F, PRE4G

Leadership training has been found to create a positive impact on one's leadership self-efficacy. However as seen in Table 9.4, for international students, organized leadership training at the campuslevel was not found to have a positive impact. When accounting for covariates, participating in a leadership training or education experience had a negative effect similar to an employer on the students' leadership self-efficacy. This disjoint may be a result of the nature of the leadership training. These trainings and activities are geared to the majority of the students on campus-domestic students - which may have a contrasting effect on international students. Table 9.4 Impact of Leadership Training on International Students' LSE 
9 International Students' Experiences Developing Leadership Capacity on Host Campuses

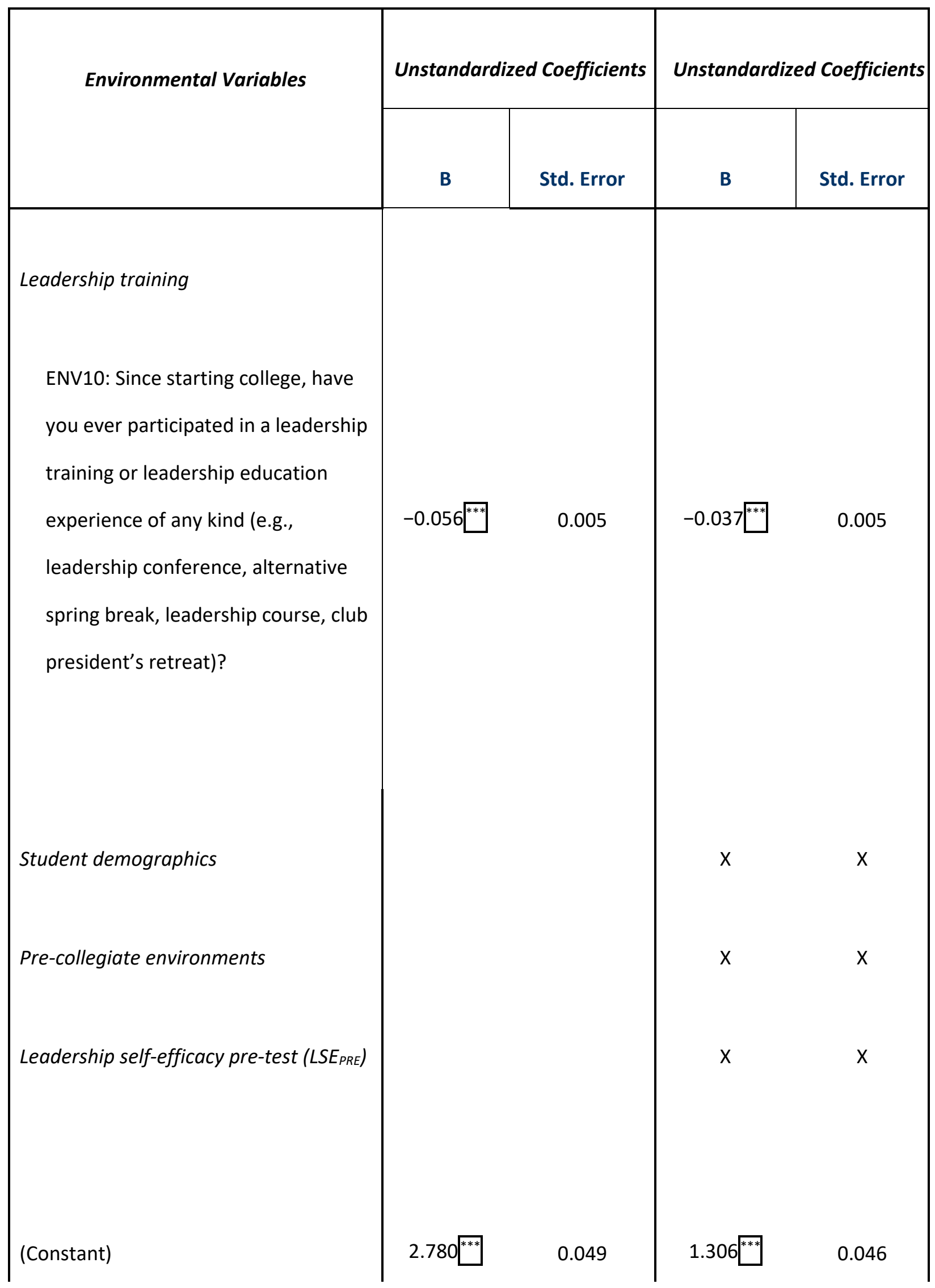


NOTES:

$\stackrel{* * * *}{*}<0.01$

(1) Student demographics included international student status, gender, race, academic major, class standing, class GPA, interactions: gender * major, gender * race

(2) Pre-collegiate environments included variables PRE3A, PRE3B, PRE3C, PRE4A, PRE4C, PRE4D, PRE4F, PRE4G

Campus environments played an important role in the development of international students' leadership self-efficacy. While various campus activities showed positive gains in self-efficacy of leadership, others did not. In the next section, the study will examine more closely how campus environments impact the diverse subgroup of international student populations.

\section{Discussion of Results}

The findings show that the campus environment impacts international students differently compared to the literature on domestic students. While others have found off campus employment and community service to be positive predictors of leadership development (Astin, 1993; Astin \& Sax, 1998; Kezar \& Moriarty, 2000; Lambert, Terenzini, \& Luttuca, 2006), results from this study were contrasting. For international students, working off campus and community service appeared not to be positive predictors on their LSE. Reasons for this could be, first of all, because of immigration law. Most international students are unable to seek employment off campus. In addition, international students seldom participate in community service opportunities. Most international students do not have the transportation necessary to participate. 
9 International Students' Experiences Developing Leadership Capacity on Host Campuses

As expected, first year or freshman seminar courses have a positive effect on international students' LSE as does study abroad. Practicums, internships, and clinical experiences also do not have positive impacts. This could be a result of navigating different systems, language barriers, and discrimination outside of campus. It could also be a result of students studying academic majors that may not require these experiences.

As expected and similar to previous research (Bardou et al., 2003; Cooper, Healy, \& Simpson, 1994; Komives et al., 2006; McCormick et al., 2002; Romano, 1996), students who hold positional leadership increase their self-efficacy. This is also true for international students; however, positional leadership off campus does not have as positive of an impact as those on campus. It appears that off campus activities are less impactful for international students. Similarly, since very few international students would engage in U.S. military training programs, this kind of activity did not appear to be a positive predictor on their LSE. One could also make the same attributes to political involvement. However, smaller group activities, such as arts/theater/music, identity-based organizations, international interest organizations, and multi-cultural fraternity and sororities had very positive impacts on their leadership self-efficacy. The smaller nature of the organization and the subjects of interest may attract more international students and provide a welcoming and inviting atmosphere for international students to participate. Since international students may not understand the American style of governance, it is not a surprise that student governance types of activities have a negative influence on their LSE. To better provide a positive environment for international students to engage in student governance and learn about governance styles in their host countries, institutions could initiate international student government-type organizations. Not only would this be of educational value, but also students would have a voice on campus to address their concerns.

While leadership education has been found to be a positive indicator of positive self-efficacy of leadership (Moriarty \& Kezar, 2000), these programs are generally targeted at domestic students and engage large groups of students. As a result, while it is likely that fewer international students participate in this kind of activity, those who do have some experience may be negatively impacted by 
the dominance of domestic students in the program and the lack of understanding of leadership from different cultures and customs. Lastly, it is not uncommon that students who feel accepted and valued exhibit higher self-efficacies than those who do not. Leadership education and training should be organized and targeted with international students in mind so that these programs can incorporate cultural values that may not be apparent for domestic students.

\section{Limitations}

Common to any research study, there are limitations to this study. First of all, the MSL survey was developed primarily for domestic students. As a result, many of the survey questions could be misinterpreted or misunderstood by international students. For example, questions regarding precollegiate experiences asking students to respond to participation in specific high school activities may not apply to international students. Many countries do not have high school varsity sports, nor do they have after-school extracurricular activities. Questions that do not have the same application to international students as domestic students, such as study abroad, could confuse student respondents and cause them to answer inaccurately. As a result, the MSL survey is limited in its generalizability due to the overrepresentation of domestic students over international students.

\section{Implications for Practice}

While campus administrators and professionals open all programs and interventions to all students, including international students, the results from this study illustrate those campus activities that administrators and professionals should further expand and develop with particular attention to international students. College administrators should consider developing leadership training and education programs specifically for their international student population. This could be achieved by partnering with campus cultural centers or identity-based organizations, which were reported to have a high impact on international students' leadership self-efficacy. 
9 International Students' Experiences Developing Leadership Capacity on Host Campuses

Campus-wide, academic departmental programs were not found to be as impactful on their leadership efficacy for international students. Campus administrators and faculty should make such programs smaller and more intimate in nature. International students reported that smaller and identity-based, multi-cultural, or international-friendly types of organizations positively impacted their leadership efficacy and engagement on campus. Purposefully designing these campus-wide, departmental, academic programs to be targeted for international students may invite more to participate. Overall, many campuses expect that international students will take part in programming and activities available to all students on campus; however, administrators, faculty, and student affairs professionals do not realize that such an approach may alienate many students who are already struggling with the new academic system, cultural shock, and instances of discrimination.

Lastly, positional leadership opportunities in campus student government have been found to positively impact students' self-efficacy of leadership. However, for international students, these experiences had a negative impact on their leadership efficacy. This could be a result of language barriers, cultural differences, discrimination, and misunderstanding of ways of governance that prevent international students from positively engaging in these kinds of opportunities. College administrators and institutions should create student government bodies specifically geared for international students to address issues pertinent to international students on campus. This opportunity would allow international students to participate in positional leadership roles in an environment inviting and empowering for international students with their cultural norms incorporated, instead of them having to assimilate to the dominate American cultural norms. Moreover, this would allow international students to have a voice to address concerns on campus while learning about governing and governance styles in their host country. The findings from this study suggest that more attention needs to be given to international students' engagement and development of leadership capacity on American host campuses. As a growing student constituent on American host campuses, international students will provide a growing breadth of alumni support and development for institutions while recruiting prospective students to meet the demand of American higher education. 


\section{Conclusion}

Examining the college student experience through the lens of the dominant, traditional, domestic student experience is often the primary perspective for higher education and student affairs professionals seeking to engage international students. The results and findings from this study contribute to the understanding of the use of rational myths as justification for the application of existing domestic student programs for international students (Pascarella, 2006). In order to better impact and influence the international student experience on host campuses, programs and services should be targeted and modified to attract and engage international students. Moreover, depending on the program or service, student affairs practice should understand that the international student population is very diverse and heterogeneous, warranting the understanding of various involvement and development patterns of different ethnic students within this diverse group. Similar to higher education's understanding of the diverse lived experiences of domestic students, our international students are just as complex.

While this study focused on the leadership self-efficacy of international students, it also prompted the profession to examine ways to better engage and develop leadership capacity in our international students. Better understanding how international students are engaging with our campuses and the community around them allows institutions and professionals to reexamine how higher education and student affairs can develop educational interventions and programs.

\section{References}

Antonio, A. L. (2001). The role of interracial interaction in the development of the leadership skills and cultural knowledge and understanding. Research in Higher Education, 42, 593-617.

Astin, A. W. (1991). Assessment for excellence. New York, NY: American Council of Education and Macmillan. 
9 International Students' Experiences Developing Leadership Capacity on Host Campuses

Astin, A. W. (1993). What matters in college: Four critical years revisited. San Francisco, CA: Jossey-Bass. Astin, A. W. (1997). Liberal education and democracy: The case for pragmatism. Liberal Education, 83, 415.

Astin, A. W., \& Astin, H. S. (Eds.). (2000). Leadership considered: Engaging higher education in social change. Battle Creek, MI: W.K. Kellogg Foundation.

Astin, A. W., \& Sax, L. J. (1998). How undergraduates are affected by service participation. Journal of College Student Development, 39(3), 251-263.

Astin, H. S., Astin, A. W., Boatsman, K., Bonous-Hammarth, M., Chambers, T., \& Goldberg, S. (1996). A social change model of leadership development: Guidebook (Version III). Higher Education Research Institute, University of California, Los Angeles. Retrieved from www.heri.ucla.edu/PDFs/pubs/ASocialChangeModelofLeadershipDevelopment.pdf.

Bandura, A. (1997). Self-efficacy: The exercise of control. New York, NY: Freeman. education. San Francisco, CA: Jossey-Bass. international students: A longitudinal study. Journal of College Student Development, 29(5), 218-222.

Bardou, K., Byrne, S., Pasternak, V., Perez, N., \& Rainey, A. (2003). Self-efficacy and student leaders: The effects of gender, previous leadership experiences, and institutional environment. Journal of the Indiana University Student Personnel Association, 33-48.

Chemers, M. M. (2000). Leadership research and theory: A functional integration. Group Dynamics: Theory, Research and Practice, 4, 27-43.

Chemers, M. M., Watson, C. B., \& May, S. T. (2000). Dispositional affect and leadership effectiveness: A comparison of self-esteem, optimism, and efficacy. Personality and Social Psychology Bulletin, 26(3), 267-277.

Chhokar, J. S., Brodbeck, F. C., \& House, R. J. (Eds.). (2013). Culture and leadership across the world: The GLOBE book of in-depth studies of 25 societies. London, UK: Routledge.

Cooper, D. L., Healy, M. A., \& Simpson, J. (1994). Student development through involvement: Specific changes over time. Journal of College Student Development, 35, 98-102.

Crawford, S. D., Couper, M. P., \& Lamias, M. J. (2001). Web surveys: Perceptions of burden. Social Science Computer Review, 19, 146-162.

Day, D. V., Harrison, M. M., \& Halpin, S. M. (2009). An integrative approach to leader development. New York, NY: Routledge.

Denzine, G. (1999). Personal and collective efficacy: Essential components of college students' leadership development. Concepts \& Connections, 8(1), 3-5.

Dugan, J. P. (2006). Involvement and leadership: A descriptive analysis of socially responsible leadership. Journal of College Student Development, 47(3), 335-343.

Dugan, J. P., \& Haber, P. (2007). Examining the influences of formal leadership programs on student educational gains. Concepts \& Connections, 15(3), 7-10. 
Dugan, J. P., \& Komives, S. R. (2007). Developing leadership capacity in college students: Findings from a national study. A report from the Multi-Institutional Study of Leadership. College Park, MD: National Clearinghouse for Leadership Programs.

Dugan, J. P., \& Komives, S. R. (2011). Influences on college students' capacity for socially responsible leadership. Journal of College Student Development, 51, 525-549.

Higher Education Research Institute. (1996). A social change model of leadership development: Guidebook version III. College Park, MD: National Clearinghouse for Leadership Programs.

Hofstede, G. (1980). Culture and organizations. International Studies of Management \& Organization, 10(4), 15-41.

Howard, G. S. (1980). Response shift bias: A problem in evaluating interventions with pre/post selfreports. Evaluation Review, 4, 93-106.

Howard, G. S., \& Dailey, P. R. (1979). Response-shift bias: A source of contamination in self report measures. Journal of Applied Psychology, 64, 114-150.

House, R. J., Hanges, P. J., Javidan, M., Dorfman, P. W., \& Gupta, V. (Eds.). (2004). Culture, Leadership, and Organizations: The GLOBE Study of 62 Societies. Thousand Oaks, CA: Sage Publications.

Kezar, A., Carducci, R., \& Contraras-McGavin, M. (2006). Rethinking the "L" word in higher education: The revolution in research on leadership. ASHE Higher Education Report (Vol. 31, No. 6). San Francisco, CA: Jossey-Bass.

Kezar, A., \& Moriarty, D. (2000). Expanding our understanding of student leadership development: A study exploring gender and ethnic identity. Journal of College Student Development, 4(1), 55-69.

Komives, S. R., \& Dugan, J. P. (2010). Contemporary leadership theories. In R. A. Couto (Ed.), The handbook of political and civil leadership (pp. 109-125). Thousand Oaks, CA: Sage Publications, Inc.

Komives, S. R., Longerbeam, S., Owen, J. O., Mainella, F. C., \& Osteen, L. (2006). A leadership identity development model: Applications from a grounded theory. Journal of College Student Development, 47, 401-418.

Komives, S. R., Owen, J. O., Longerbeam, S. D., Mainella, F., \& Osteen, L. (2005). Developing a leadership identity: A grounded theory. Journal of College Student Development, 46(6), 593-611.

Kuh, G. D. (2001). Assessing what really matters to student learning: Inside the National Survey of Student Engagement. Change, 33(3), 10-17, 66.

Lambert, A. D., Terenzini, P. T., \& Luttuca, L. R. (2006). More than meets the eye: Curricular and programmatic effects on student learning. Research in Higher Education, 48, 141-168.

Lee, C., \& Early, P. S. (1992). Comparative peer evaluations of organizational behavior theories. Organization Development Journal, 10(4), 37-42.

Machida, M., \& Schaubroeck, J. (2011). The role of self-efficacy beliefs in leadership development. Journal of Leadership \& Organizational Studies, 18(4), 459-468. 
McCormick, M. J., Tanguma, J., \& Lopez-Forment, A. S. (2002). Extending self-efficacy theory to leadership: A review and empirical test. Journal of Leadership Education, 1(2), 1-15.

Mori, S. (2000). Addressing the mental health concerns of international students. Journal of Counseling and Development, 78(2), 137-144.

Moriarty, D., \& Kezar, A. (2000). The new leadership paradigm: Expanding our notions of leadership development. NetResults, NASPA's E-Zine for Student Affairs Professionals. Retrieved from www.naspa.org/NetResults/article.cfm?ID=18.

Murphy, S. E. (2002). Leader self-regulation: The role of self-efficacy and multiple intelligences. In Kravisde Roulet Leadership Conference, 9th Apr, 1999, Claremont McKenna Coll, Claremont, CA, US. Lawrence Erlbaum Associates Publishers.

Newcomb, T. M. (1962). Student peer-group influence. In N. Sanford (Ed.), The American College (pp. 469-488). New York, NY: Wiley.

Paglis, L. L. (2010). Leadership self-efficacy: Research findings and practical applications. Journal of Management Development, 29, 771-782.

Pascarella, E. T. (2006). How college affects students: Ten directions for future research. Journal of College Student Development, 47, 508-520.

Pascarella, E. T., \& Terenzini, P. T. (2005). How college affects students: A third decade of research. San Francisco, CA: Jossey-Bass.

Roberts, D. C. (2003). Crossing the boundaries in leadership program design. In C. Cherry, J. J. Gardiner, \& N. Huber (Eds.), Building Leadership Bridges 2003 (pp. 137-149). College Park, MD: International Leadership Association.

Rohs, F. R. (1999). Response shift bias: A problem in evaluating leadership development with self-report pretest-posttest measures. Journal of Agricultural Education, 40(4), 28-37.

Rohs, F. R. (2002). Improving the evaluation of leadership programs: Control response shift. Journal of Leadership Education, 1(2), 1-12.

Rohs, F. R., \& Langone, C. A. (1997). Increased accuracy in measuring leadership impacts. Journal of Leadership Studies, 4(1), 150-158.

Romano, C. (1996). A qualitative study of women student leaders. Journal of College Student Development, 37(6), 676-683.

Ronen, S., \& Shenkar, O. (1985). Clustering countries on attitudinal dimensions: A review and synthesis. Academy of Management Review, 10(3), 435-454.

Seidman, A. (Ed.). (2005). College student retention: Formula for student success. Santa Barbara, CA: Greenwood Publishing Group.

Smith, P. B., Dugan, S., \& Trompenaars, F. (1996). National culture and the values of organizational employees: A dimensional analysis across 43 nations. Journal of cross-cultural psychology, 27(2), 231264. 
Thompson, M. D. (2006). Student leadership process development: An assessment of contributing college resources. Journal of College Student Development, 47, 343-350.

Weidman, J. C. (1989). Undergraduate socialization: A conceptual approach. In J. C. Smart (Ed.), Higher education: Handbook of theory and research (Vol. 5, pp. 289-322). New York, NY: Agathon.

Zimmerman-Oster, K., \& Burkhardt, J. (1999). Leadership in the making: Impact and insights from leadership development programs in U.S. colleges and universities. Battle Creek, MI: W.K. Kellogg Foundation. 